unfortunately the latter accidentally became saturated with spirits of wine in which a snake had been preserved, so that it was impossible to taste them.-E. L. Ragonot, 33 Rue de Buffon, Paris (Science Gossip).

We hear that the "Ladybirds," which excited so much curiosity last autumn, have reappeared in large numbers in the neighbourhood of New Wandsworth. So early an appearance will surprise most of us who have been wont to regard these visitors as summer guests. - Nature, March 3 .

\title{
LIST OF COLEOPTERA.
}

TAKEN AT GRIMSBY, ONTARIO, BV J. PEITIT.

(Continued from page 66.)

PHALACRIDA.

Olibrus, Er.

*Bicolor, Er.

*Pallipes, Say?

NITIDULIDA.

Cercus, Latr.

*Abdominalis, Er.

Brachypterus, Kugel.

Urticre, Fab.

Colastus, Er.

* Semitectus, Say.

*Unicolor, Say.

Truncatus, Rand.

Carpophilus, Leach.

Niger, Say.

Discoideus, Lec.

Conotelus, Er.

*Obscurus, Er.

EPURAA, $E r$.

*Nigra, Máklin.

Helvola, $E r$.

Boreela, Er.

Nitidula, Fab.

Bipustulala, Fab.

OMosita, ER.

Colon. Linn.
Phenolia, Er.

Grossa, Fab.

Stelidota, $E r$.

*Octomaculata, Say.

Cryptarcha, Slizuck. Ampla, Er.

Ips, Fab.

Fasciatus, Oliz. 4-Signatus, Say.

*Obtusus, Say.

Sanguinolentus, Oliv.

Confluens, Say.

Dejeanii, Kirby.

Pityophacus, Shuck. Bipunctatus. Say.

Rhiz ophagus, Herbst.

* Dimidiatus, Mann.

*Remotus, Lec.

MONOTOMIDA.

Bactridium, Lec.

Nanum, Er.

*Striatum, Lec.

Monotoma, Herbst.

Parallelum, Lec.

TROGOSITID $Æ$.

ALINDRIA, Er.

Cylindrica, Enc
Trogosita, Oliv.

*Corticalis, Mels.

* Intermedia, Horn.

Dubia, Meis.

*Collaris, Sturm.

Castanea, Mels.

Laticollis, Horn.

Bimaculata, Mels.

Nosodes, Lec.

Silphides, Newm. ${ }^{1}$

Peltis, Kug.

* Fraterna, Rand.

4-Lineata, Mels.

Thymales, Latr.

Fulgidus, $E r$.

COLYDIIDE.

Ditoma, Illig.

4-Guttata, Say.

Synchita, Helize.

*Fuliginosa,

Cicones, Curtis.

Marginalis, Mels.

Colyolum, Fab.

* Lineola, Say.

Bothrideres, Er. * Creminatus, Say.

* Species marked with an asterisk huve not been included in the list of Canadian Coleoptera.

t. A single specimen picked up on the shore of the Lake, October $t, 1868$. 


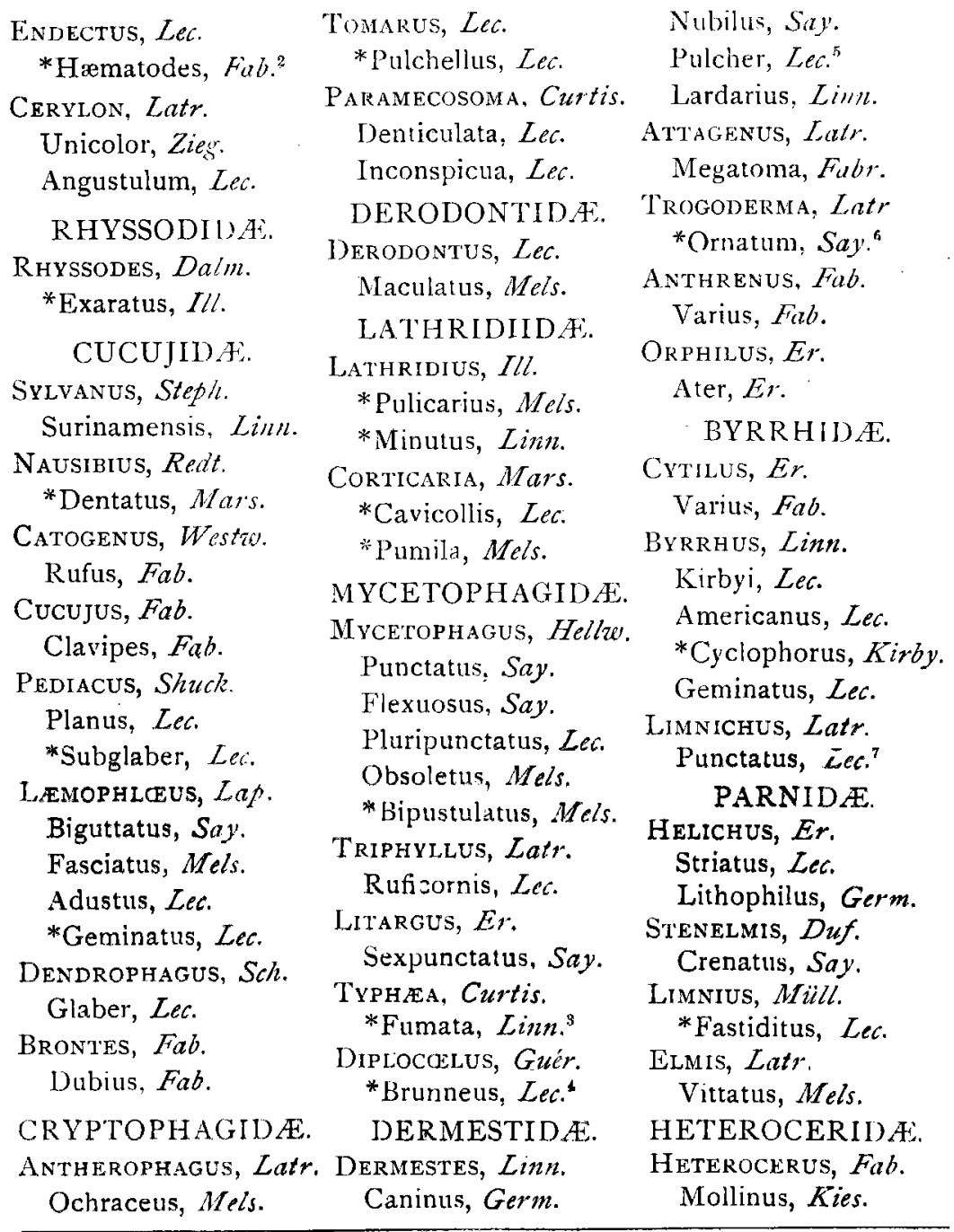

2. Under pine bark, May $27^{\text {th. }}$.

3. Found in scores under rails from which a hay-stack had been removed: January and April.

4. In moss on a fallen maple-tree ; latter part of July.

5. Taken in January under the bark of a dead elru.

6 . Bred from larva found in a case of insects.

7. Found under stones at the margin of a creek ; in July. 


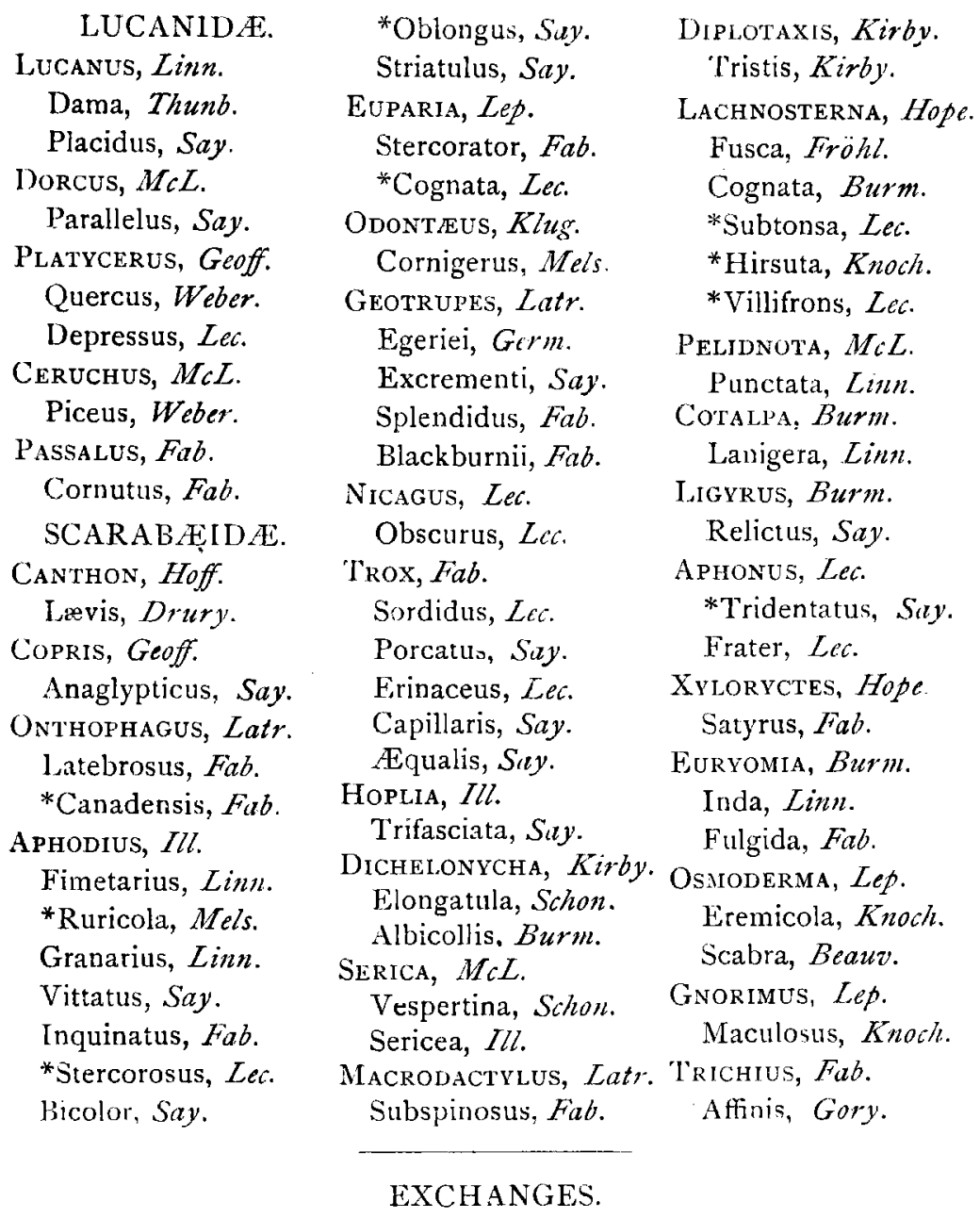

Sick Motus.-Eggs of B. Yama-mai, Pernyi, and of the white variety, free from disease, also of $B$. mori, for rare species of Canadian Lepidoptera.-W. V. Andrews, Room I 7 , No. I37 Broadway, New York.

Coleoptera.-Species desired from Canada, especially the eastem region; can give in exchange Southern and Californian forms, as well as those from the New England States. -P. S. Sprague, 227 Broadway, South Boston, Mass. 